\title{
Legal Status of Law Elucidation in The Indonesian Legislation System
}

\author{
Ilham Fajar Septian*, Ali Abdurahman** \\ DOI: https://doi.org/10.22304/pjih.v8n1.a5
}

Submitted: November 11, 2020 | Accepted: April 6, 2021

\begin{abstract}
Law elucidation is the interpretation of norms contained in the body of the law. Since the Constitutional Court reviewed the elucidation, several legal issues have arisen regarding law elucidation in the Indonesian Legislation System. The first is the formal (binding force) and material (material content) legal status of the law elucidation. The second is the extent to which the Constitutional Court can review the law elucidation. This study employed normative juridical and evaluative methods; and generates several conclusions. First, the law elucidation has binding legal force. Second, there are two forms of the elucidation content: (1) interpretation in the form of norm; and (2) interpretation that is not in the form of norm. Third, the elucidation can be reviewed if it contradicts the body of the law, other the laws that regulate the same substance, or contrary to the 1945 Constitution. Fourth, the elucidation needs to be separated from the law framework. Consequently, the elucidation does not contain essential content and does not cause constitutional problems if the content is problematic. Lastly, the elucidation needs to contain the aims and objectives of each article's existence. Therefore, the law enforcers can implement the law according to the legislators' wishes.
\end{abstract}

Keywords: the law elucidation, legal status, legislation system.

\section{Status Hukum Penjelasan Undang-Undang dalam Sistem Peraturan Perundang- Undangan Indonesia}

\begin{abstract}
Abstrak
Penjelasan undang-undang merupakan tafsir dari norma yang terdapat pada batang tubuh undang-undang. Akan tetapi, beberapa Putusan Mahkamah Konstitusi memperlihatkan bahwa penjelasan bermuatan norma dan berkekuatan hukum mengikat. Hal tersebut menunjukan status hukum penjelasan undang-undang dalam sistem peraturan perundangundangan Indonesia, baik dari segi formil (kekuatan mengikat) maupun materiil (materi muatan), tidaklah jelas. Persoalan status hukum tersebut berkaitan pula dengan sejauhmana Mahkamah Konstitusi dapat menguji penjelasan. Oleh sebab itu, persoalan status hukum penjelasan undang-undang dan sejauhmana Mahkamah Konstitusi dapat menguji penjelasan undang-undang perlu diteliti. Dengan menggunakan metode yuridis normatif dan evaluatif, artikel ini menghasilkan beberapa kesimpulan. Pertama, penjelasan
\end{abstract}

PADJADJARAN Journal of Law Volume 8 Number 1 Year 2021 [ISSN 2460-1543] [e-ISSN 2442-9325]

Student of Law Studies with Specialty on Constitutional Law, the Faculty of Law, Universitas Padjadjaran, J. Dipati Ukur Nomor 35 Bandung, ilham16002@mail.unpad.ac.id.

** Lecturer of the Department of Constitutional Law, the Faculty of Law, Universitas Padjadjaran, Jl. Dipati Ukur Nomor 35 Bandung, S.H., M. Hum., Dr. (Universitas Padjadjaran), abdurahman@unpad.ac.id. 
undang-undang memiliki kekuatan hukum mengikat. Kedua, terdapat dua bentuk materi muatan dari penjelasan, yakni tafsir yang berbentuk norma dan tafsir yang tidak berbentuk norma. Ketiga, penjelasan dapat diuji, dibatalkan, atau dinyatakan konstitusional/inkonstitusional bersyarat apabila bertentangan dengan batang tubuh undang-undang yang sama, undang-undang lain yang mengatur substansi yang sama, atau bertentangan dengan konstitusi. Keempat, penjelasan perlu dipisahkan dari kerangka undang-undang agar tidak menimbulkan masalah konstitusional serta tidak perlu dibatalkan Mahkamah Konstitusi apabila isinya bermasalah dan agar penjelasan tidak memuat isi yang sifatnya esensial. Terakhir, penjelasan perlu memuat maksud dan tujuan dari keberadaan masing-masing pasal agar penegak hukum dapat melaksanakan penerapan hukum sesuai kehendak pembentuk undang-undang.

Kata Kunci: penjelasan undang-undang, sistem peraturan perundang-undangan, status hukum.

\section{A. Introduction}

The law elucidation is part of the law framework (kenvorm) that becomes a reference for further understanding the arrangement of specific matters. The law elucidation usually interprets legal terms that have not been detailed in the body of the law to clarify the articles' normative arrangement. ${ }^{1}$ Therefore, the elucidation of the law is important in the Indonesian legislation system.

Problems related to law elucidation emerged following a judicial review of the law elucidation for the first time on the review of the Elucidation of Article 59 paragraph (1) of Law Number 32 of 2004 on the Regional Government (Regional Government the Law of 2004), known as case Number 005/PUU-III/2005. The elucidation states as follows.

"Political parties or coalitions of political parties in this provision are political parties or coalitions of political parties that have seats in the Regional People's Representative Council."

In the legal consideration of its decisions, the Constitutional Court states that it has the authority to carry out a judicial review of the law elucidation because the elucidation is a part of the law being reviewed. ${ }^{2}$

This decision annulled the elucidation of the article because it contains new norms. It contradicts with Law Number 10 of 2004 on the Establishment of Legislation (2004 Legislation Establishment Law). It states that the elucidation is exclusively legislators' official interpretation and it cannot contain norms. The content of the elucidation is also contrary to Article 59 paragraph (1) and (2) in the body of the Regional Government the Law of 2004. It states that political parties or coalitions of political parties that can participate in regional head elections are parties that have $15 \%$ of the seats in the Regional People's Representative Council

Jimly Asshiddiqie, Perihal Undang-Undang, Third Printing, Jakarta: Rajawali Press, 2014, p. 135.

The Decree of the Constitutional Court Number 005/PUU-III/2005, pp. 29-38. 
and $15 \%$ of the votes in the general election of Regional People's Representative Council. Furthermore, the Constitutional Court also stated that the elucidation was contrary to Article 1 paragraph (3), Article 18 paragraph (4), and Article 28D paragraph (1) and (3) of the 1945 Constitution of the Republic of Indonesia (1945 Constitution). ${ }^{3}$

On the other hand, in the Decree Number 3/PUU-XIII/2015, the Constitutional Court's stance is different and confusing. At that point, the Constitutional Court reviewed the Elucidation of Article 47 paragraph (2) letter e part c of the Law Number 22 of 2009 on the Road Traffic and Transportation (the Road Traffic and Transportation Law). It defines special vehicle,

"is a specially designed motorized vehicle that has certain functions and designs, among others... c. heavy equipment, including bulldozers, tractors, stoomwalls, forklifts, loaders, excavators and cranes;... ".

The Constitutional Court states that the elucidation's formulation was not the norm because the sentence structure could not be interpreted as a command, authorization, permission, prohibition, and deviation from a rule. There was no subject, predicate, or object, and only contained adverb. ${ }^{4}$ However, despite the fact that it was considered not a norm, the Constitutional Court still annulled the elucidation of the article. It was considered incompatible with the concept of motorized vehicles, which could be operated on the highway, in Article 1 and Article 7 of the Road Traffic and Transportation Law. ${ }^{5}$ It also contradicts Article 1 paragraph (3) and Article 28D paragraph (1) of the 1945 Constitution. $^{6}$

Then, in the last judicial review of the law elucidation, the case number 18/PUU-XVII/2019, the Constitutional Court does not annul the norms in the Law Number 42 of 1999 on Fiduciary Guarantee (the Fiduciary Guarantee Law). The Constitutional Court changed and added norms to the articles it reviewed. ${ }^{7}$ Not only added norms by giving conditionally unconstitutional decision to the articles contained in the body of Law (Article 15 paragraph (2) and (3) Fiduciary Guarantee Law), the Constitutional Court also adds the Elucidation of Article 15 paragraph (2) of Fiduciary Guarantee Law. ${ }^{8}$ This, of course, contains a problem because in the first decision that reviewed the law elucidation, the Constitutional Court states that an elucidation could be annulled because it contained norm. On the other hand, in its decision in 2019, the Constitutional Court adds new norms in the law elucidation.

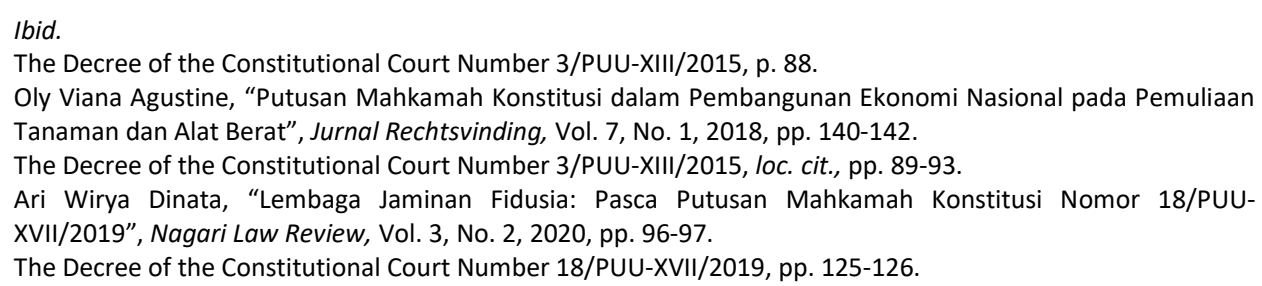


Up to now, there have been at least ten decrees of the Constitutional Court that have reviewed the law elucidation. Apart from the three decrees mentioned, there are seven other decrees. They are, among others,

1) The Decree of the Constitutional Court Number 011/PUU-III/2005 on the Review of the Law Number 20 of 2003 on the National Education System;

2) The Decree of the Constitutional Court Number 003/PUU-IV/2006 on the Review of the Law Number 31 of 1999 on the Eradication of Corruption Crime as amended by the Law Number 20 of 2001;

3) The Decree of the Constitutional Court Number 11-14-21-126 and 136/PUUVII/2009 on the Review of The Law Number 20 of 2003 on the National Education System and the Law Number 9 of 2009 on the Legal Education Entities;

4) The Decree of the Constitutional Court Number 57/PUU-IX/2011 on the Review of the Law Number 36 of 2009 on the Health;

5) The Decree of the Constitutional Court Number 79/PUU-IX/2011 on the Review of the Law Number 39 of 2008 on the State Ministry;

6) The Decree of the Constitutional Court Number 62/PUU-X/2012 on the Review of the Law Number 25 of 2002 on the Establishment of the Riau Islands Province; and

7) The Decree of the Constitutional Court Number 42/PUU-XIII/2015 on the Review of The Law Number 8 of 2015 on Amendment to The Law Number 1 of 2015 on Stipulation of Government Regulations in Lieu of the Law Number 1 of 2014 on the Elections of Governors, Regents, and Mayors into Law.

From the ten decrees, nine of them annulled the elucidation and the other one gave a conditionally unconstitutional decision. This shows that the problem of the law elucidation in Indonesia is significant.

Then, Attachment II of the Law Number 12 of 2011 on the Establishment of Legislation (2011 Legislation Establishment Law) ${ }^{9}$ states that the elucidation may not include formulations that contain norms. It may not expand, narrow, or add to the meaning of norms in the body of the law. In addition, it may not contain delegation formulas, and should not be the legal basis for any other rules. This means that The Law only wants the law elucidation to be interpreted and does not have binding legal force. However, the Decree of the Constitutional Courts that annulled the law elucidation above show that the Constitutional Court acknowledged that the law elucidation has binding legal force before it is annulled. Based on the decisions shown earlier, the Constitutional Court annulled the elucidation because it was part of the law. Thus, making the elucidation as part of the law framework becomes a problem as well.

This law has been amended by Law Number 15 of 2019 on Amendment to Law Number 12 of 2011 on the Establishment of Legislation. 
Therefore, it is clear that there is a problem regarding the unclear legal status of the legislation elucidation, especially the law elucidation. ${ }^{10}$ This article tries to answer two main questions. First, regarding the legal status of the law elucidation from a formal perspective (the binding force of the law elucidation and its placement as part of the law framework) and a material perspective (the content of the law elucidation). Second, the extent to which the Constitutional Court can use the law elucidation as the object of judicial review. The unclear legal status of the law elucidation will be evaluated, mainly based on the dynamic and static aspects of legal norm theory (to discuss norm and interpretation), hermeneutic theory (to discuss interpretation), and theory of the basics of legislation (to discuss the law framework).

This study is different from another study that discusses the law elucidation from Hermanto et.al. ${ }^{11}$ The article discusses the position of the law elucidation based on the three Decree of the Constitutional Courts and states that the position of the elucidation is only to contain official interpretations and should not contain legal norms.

It must be admitted that the article has a discussion similar to the research conducted by the authors in the issue of material legal status that is regarding the content of the elucidation. However, the previous article simplifies the matter of interpretation and norm because it does not explain in detail why the two (interpretation and norm) are different, even though the study states that the law elucidation can only contain interpretation and cannot contain norm. In other words, it can only contain one of the two. Therefore, the study is of position that this problem needs to be further deepened based on the three mentioned theories.

Furthermore, the previous article also did not explain the formal legal status regarding the binding force of the law elucidation and its placement as part of the law framework and the extent to which the Constitutional Court can review the law elucidation. Therefore, to study the things is urgent. This study is a type of normative juridical research because it examined the legal principles and the legal norm ${ }^{12}$ by library research. This study is an evaluative study to an unclear legal status of law elucidation in the Indonesian legislation system.

The approaches used include historical, legislation, case, and conceptual approaches using various theories or doctrines. ${ }^{13}$ A comparative law approach was also applied. It used three essential elements in the comparative law study. They

10 This article limits its study to law elucidation because this article researched The Decree of the Constitutional Court which can only review law and cannot review other legislation.

11 See Bagus Hermanto (et.al), "Penegasan Kedudukan Penjelasan Suatu Undang-Undang: Tafsir Putusan Mahkamah Konstitusi", Jurnal Legislasi Indonesia, Vol. 17, No. 3, 2020.

12 Soerjono Soekanto and Sri Mamudji, Penelitian Hukum Normatif: Suatu Tinjauan Singkat, Jakarta: UI Press, 2003, p. 23.

13 Johny Ibrahim, Teori dan Metodologi Penelitian Hukum Normatif, Malang: Bayu Media Publishing, 2006, p. 32. 
are, among others, (1) comparatum (the elements being compared), that is the law elucidation; (2) comparandum (the subject of comparison), namely Indonesian law (civil law) with Dutch law (civil law) and Australian law (common Law); and (3) tertium comparationis (similarity in characteristics of the countries being compared), namely the direct and active involvement of the government in the deliberation of the law in the parliaments of these countries. ${ }^{14}$

The data were secondary data consisting of primary legal materials. They are (1) laws and decisions regulating the establishment and review of the law in Indonesia; (2) laws with reviewed elucidations, which have existed since the independence period, either before or after the establishment of law legislation (and related to issues of constitutional the Law); and (3) Constitutional Court's decrees that reviewed the law elucidation. The last one also includes various studies, books, journal articles, papers, or other writings from experts who carry out analysis and explain primary legal materials regarding the law elucidation.

\section{B. Legal Status of The Law Elucidation in Indonesia}

1. Formal and Material Legal Status of The Law Elucidation

a. Formal Legal Status

Discussion on the formal legal status of the elucidation will explain the binding force of the law elucidation. The binding force will be related to its placement as part of the law framework. Therefore, it will be explained in advance regarding the placement of elucidation in the law framework. From that explanation, then the conclusion of whether or not law elucidation has binding legal can be drawn.

The law elucidation in Indonesia is part of the law framework since the issuance of Indonesia's first post-independence the Law, the Law No. 1 of 1945 on the Regulation on the Position of Regional National Committees. Together with all parts of the law framework, the elucidation is announced in front of the Central National Committee building. However, it had not been contained yet in the Official Gazette and the Supplement to the Official Gazette. ${ }^{15}$

Promulgation in the Official Gazette and the Official Newspaper and the regulation on this matter happened in 1950. It includes Law Number 2 of 1950 on the Issuance of the Official Gazette, and the Official Newspaper of Indonesia. It also covers the establishment of Federal Law and Government Regulation as Federal Law promulgated in the Official Gazette of Indonesia of 1950 Number 1. The emergency law was later stipulated by the law Number 2 of 1950 (The Law on the Official Gazette), which was promulgated in the Official Gazette of 1950 Number 32.

14 Ratno Lukito, Perbandingan Hukum: Perdebatan Teori dan Metode, Yogyakarta: Gadjah Mada University Press, 2016, p. 23.

15 Maria Farida Indrati Soeprapto, Ilmu Perundang-undangan 2 (Proses dan Teknik Penyusunan), Yogyakarta: Kanisius, 2018, p. 155. 
Unfortunately, the Law does not mention the existence of the Supplement to the Official Gazette containing the Law elucidation. However, still in 1950, the Supplement to the Official Gazette had begun to exist, for example in Law Number 4 of 1950. It was promulgated in Official Gazette of 1950 Number 45 and its elucidation in the Supplement to the Official Gazette Number 27. ${ }^{16}$ The Supplement to the Official Gazette, which is not regulated in the law on the Official Gazette of Indonesia, can imply that the existence of the law elucidation of the Supplement to the Official Gazette is a legislation practice in Indonesia. Arrangements for the Law elucidation and the promulgation in the Supplement to the Official Gazette are only regulated for the first time in Presidential Decree Number 44 of 1999 on the Technique for the Formulation of Legislation and Forms of Draft, Draft Government Regulation, and Draft Presidential Decree. The 2004 Legislation Establishment Law and the 2011 Legislation Establishment Law subsequently regulate them.

This is in contrast to the Netherlands and Australia. In the Netherlands, the law elucidation is called "Memorie van Toelichting", which is not part of law framework. It is a part of the Parliamentary Document (Kamerstuk). The elucidation contains the royal message, a draft law (bill), a memory of elucidation (memorie van toelichting), Raad van State's advice, a further report in the form of a comment on Raad van State's advice from the government, a note on improvement, an amendment to the bill, a memory of change/amendment, and others. That is why memorie van toelichting cannot be found in the law framework and is not promulgated in the Staatsblad, ${ }^{17}$ but can be found in the Parliamentary Documents with the third serial number. ${ }^{18}$

The Utrecht University Library's official website states that the Parliamentary Document containing memorie van toelichting has existed since $1814 .{ }^{19}$ The current regulation regarding Parliamentary Document is in Article 151 Reglement van Orde van de Tweede Kamer (Parliamentary Rules of Conduct) and specifically regarding memorie van toelichting in the Besluit van de Minister-President, Minister van Algemene Zaken, van 22 December 2017, nr. 3215945, houdende vaststelling van de tiende wijziging van de Aanwijzingen voor de regelgeving, promulgated in Staatscourant 2017, 69426. ${ }^{20}$ Thus, different with the opinion of Indonesian legal

\footnotetext{
16 Until now, the authors have not found the existence of the Supplement to the Official Gazette that first existed (the Supplement to the Official Gazette Number 1).

17 The term for the Official Gazette in the Netherlands.

18 Kennis-en Exploitatiecentrum Officiële Overheidspublicatie, "Veelgestelde vragen over Wet- en regelgeving", https://www.overheid.nl/veelgestelde-vragen/veelgestelde-vragen-over-wet-en-regelgeving\#BWB004, accessed on August 2020.

19 Universiteit Utrect, "Wet- en regelgeving: Nederlandse wetgeving", https://libguides.library.uu.nl/c.php?g=202157\&p=1331397, accessed on August 2020.

20 Ministerie van Justitie en Veiligheid, "Besluit van de Minister-President, Minister van Algemene Zaken, van 22 december 2017, nr. 3215945, houdende vaststelling van de tiende wijziging van de Aanwijzingen voor de regelgeving", https://zoek.officielebekendmakingen.nl/stcrt-2017-69426.html, accessed on August 2020.
} 
experts, ${ }^{21}$ the law elucidation before Indonesian independence is the same as in the Netherlands. It was not promulgated in the Supplement to the Official Gazette (Bijblad). This can be proven by the absence of the law elucidation or the memorie van toelichting in Bijblad. The Bijblad in the past contained ministerial or officiallevel decrees such as the Decree of the Director of Transportation and Irrigation on Traffic and Road Intersection Management dated September 26, 1936 (Wegverkeersbluit-verkeer en waterstaat - Bjiblad 13699) ${ }^{22}$ or the Decree of the Director of Home Affairs on the Driving License dated 8 October 1936 (Wegverkeersbluit-binnenlands bestuur - Bijblad No. 14137). ${ }^{23}$

According to Indonesian legal experts, the practice of using law elucidation in Australia as a common law adherent is rare. ${ }^{24}$ However, Australia also regulates the existence of the law elucidation called "Explanatory Memorandum". It is regulated in the section 15AB of the Acts Interpretation Act $1901 .^{25}$ Based on the Act, explanatory memorandum in Australia is not part of the law framework and become extrinsic material. They are documents or materials submitted by the government to parliament and used to assist in deliberating bills in parliament. They are usually stored in parliament archive or library and help the judges to interpret laws. ${ }^{26}$ The explanatory memorandum arrangement was only included in the Act in 1984 with the amendment of the Acts Interpretation Act 1901. However, the explanatory memorandum has existed since 1905, to be precise, in the discussion of Copyright Bill 1905 in the Senate in August 1905. ${ }^{27}$

Regarding the formal legal status of the law elucidation in Indonesia, Manan and Astawa state that the elucidation was made and contained in the Supplement to the Official Gazette as only "memorie van toelichting". It was not a source of formal law and had no binding legal force. An elucidation binds if it is contained in body of the law, such as various definitions/meanings in the general provisions of law. ${ }^{28}$

These conclusions still deserve to be studied and analyzed. Kelsen, in his Pure Theory of Law, states that there are two aspects of legal norms. ${ }^{29}$ They are the dynamic aspect (the aspect that looks at the way of "forming" or "eliminating"

21 Sri Hajati et al., Buku Ajar Pengantar Hukum Indonesia, Second Printing, Surabaya: Pusat Penerbitan dan Percetakan Universitas Airlangga, 2018, p. 132.

22 Ichtiar Baru-van Hoeve, Himpunan Peraturan Perundang-undangan Republik Indonesia, Jakarta: Ichtiar Baruvan Hoeve, 1992, p. 1759.

Ibid., p. 1787.

I Gde Pantja Astawa in The Decree of the Constitutional Court Number 3/PUU-XIII/2015, pp. 59-60.

Patrick O'Neill, "'Was there an EM?'-Explanatory memoranda in the Commonwealth Parliament 1901-82", Australian Law Librarian, Vol. 13, No. 1, 2005, p. 7.

Ibid.

Ibid., p. 8.

Bagir Manan and I Gde Pantja Astawa in The Decree of the Constitutional Court Number 3/PUU-XIII/2015, pp. 38-39 and 60-62. Also read: Bagir Manan, Hukum Kewarganegaraan Indonesia dalam Undang-Undang Nomor 12 Tahun 2006, First Printing, Yogyakarta: FH UII Press, 2009, pp. 59-60.

29 Hans Kelsen, Pure Theory of Law, translated from the Second (Revised and Enlarged) German Edition by Max Knight, New Jersey: The Lawbook Exchange, 2005, p. 70. 
norms) and the static aspect (the aspect that looks at the content of legal norms). ${ }^{30}$ The formal legal status of the law elucidation is related to the law's dynamic aspects.

The dynamic aspect of the law is related to the issue of legal validity. Kelsen states that the legal validity ("action power" and "binding power/force") ${ }^{31}$ means that legal norms bind and must be obeyed. ${ }^{32}$ Validity is generated because a legal order (all legal norms) is based on a basic norm. It is the reason for its validity and the overall legal norms are valid because it is formed by procedures, which is regulated by the basic norm, the constitution, and all other norms regarding the creation of legal norms, either general or individual norms. ${ }^{33}$ General legal norms are usually declared valid and binding when promulgated in the official gazette or official newspaper. ${ }^{34}$ Kelsen's concept of legal validity is closely related to the distinguishing characteristics of the law from other norms/rules (such as morals) according to Hart, which can be changed intentionally, immediately, and at a certain time as desired directly, with a legislative enactment, which is an arbitrary human decision. ${ }^{35}$

Therefore, all parts of the legal framework have binding legal force as long as they are promulgated. Thus, the formal legal status of the law elucidation in Indonesia is different from that of the Netherlands and Australia. Although both Indonesia and the Netherlands adhere to civil law, law elucidation in Indonesia has binding legal force because it is promulgated in the Supplement to the Official Gazette. ${ }^{36}$ Consequently, every person is considered to know it. In contrast, in the Netherlands, the elucidation is not part of the law framework. It is not promulgated, is only part of a parliamentary document, and is not legally binding. The formal legal status of law elucidation in the Netherlands is exactly the same as Australia which adheres to common law because law elucidation in Australia is not included in the legal framework (extrinsic material). It is not promulgated and is kept in parliamentary archives so that it has no binding legal force.

30 Hans Kelsen, General Theory of Law and State, Translated by Anders Wedberg, Cambridge: Harvard University Press, 1949, pp. 110-113.

31 Maria Farida Indrati Soeprapto, Ilmu Perundang-undangan 1 (Jenis, Fungsi, dan Materi Muatan), Sixteenth Printing, Yogyakarta: Kanisius, 2018, pp. 39-40.

32 Hans Kelsen, Pure Theory of Law, translated from the Second (Revised and Enlarged) German Edition by Max Knight, op.cit., p. 39.

$33 \quad$ Ibid, pp. 193-230.

$34 \quad$ Ibid, pp. 254-255. Also read: Inge Cornelia van der Vlies, Buku Pegangan Perancang Peraturan PerundangUndangan, translated by Linus Doludjawa, Jakarta: Direktur Jenderal Peraturan Perundang-undangan Departemen Hukum dan Hak Asasi Manusia RI, 2005, p. 290.

35 H. L. A. Hart, The Concept of Law, Second Edition, New York: Oxford University Press, 1994, pp. 175-178.

36 Article 81 juncto Article 84 of the Establishment of Legislation Law 2011. 


\section{b. Material Legal Status}

Discussion on the material legal status will focus on discussing the material content of the law elucidation, which contains norm or contains interpretation. Therefore, the two entities need to be addressed first.

Farida stated that norms could be interpreted as a measure or standard for someone to act or behave in society or other words; norms are all rules that must be obeyed. ${ }^{37}$ According to Kelsen, norms are something that should exist or should happen, especially that humans should behave in a certain way. ${ }^{38}$

Based on the theory of basic legislation, not all parts of the law framework are norms. According to Manan and Farida, norm or formulation in the form of normative sentence in law is found in the body of the law. ${ }^{39}$ The matters are listed in the preamble, such as the statement "With the Grace of God Almighty", or consideration which contain the background for the formation of the laws from a philosophical, sociological, and juridical perspective (such as the preamble to the constitution) are not the norm (which regulate human behavior). It rather contains good political, moral, religious ideas, which are more ideological than legal. ${ }^{40}$ Likewise legal principles, even though they are listed in the articles, they have no character as the norm. ${ }^{41}$ Unfortunately, the experts do not discuss in detail other parts of the law framework, such as the closing part or the attachment of the law; it is not clear whether it is the norm or not.

According to the Constitutional Court, a provision is called as a legal norm when it contains commands, prohibitions, approves, authorizes, and/or deviates certain provisions. The fulfillment of which is enforced by a certain legal sanction. ${ }^{42}$ According to Kelsen, from the static aspect (material content) of legal norms, there are two categories of legal norms: independent and dependent legal norms. The only legal norms that are independent are those that impose sanctions, while other legal norms are dependent legal norms. These dependent legal norms include (1) command norms (to carry out certain behavior or prohibit/not to carry out certain behaviors); (2) norms that positively allow certain behavior; (3) norms that authorize certain behavior; and (4) norms that determine the meaning of other norms by defining or interpreting a concept that is in those other norms. ${ }^{43}$ This means that based on Kelsen's opinion, interpretation or meaning is one form of norms that can usually be found.

\footnotetext{
37 Maria Farida, Ilmu Perundang-undangan 1, op.cit., p. 18.

38 Hans Kelsen, Pure Theory of Law, translated from the Second (Revised and Enlarged) German Edition by Max Knight, op.cit., p. 4.

39 Bagir Manan, Dasar-Dasar Perundang-undangan Indonesia, Jakarta: Ind-Hill.Co, 1992, p. 68. Also read: Maria Farida, Ilmu Perundang-undangan 2, op.cit., p. 98.

40 Maria Farida, ibid., pp. 107-108. Also read: Hans Kelsen, General Theory of Law and State, Translated by Anders Wedberg, op.cit., pp. 260-261.

$41 \quad$ Maria Farida, ibid., p. 227.

42 The Decree of the Constitutional Court Number 3/PUU-XIII/2015, p. 88.

43 Hans Kelsen, Pure Theory of Law, translated from the Second (Revised and Enlarged) German Edition by Max Knight, op.cit., pp. 54-58.
} 
Kelsen further even argues that every law enforcement carried out by law enforcers, such as court decisions that apply laws or enforcing court decisions by law enforcers, is the interpretations that also create law. This interpretation is called authentic interpretation. ${ }^{44}$

The interpretation is indeed an essential aspect of law. According to Hart, laws are rules that have an open texture. This occurs because, in a large group, social control's main instruments must be rules, standards, and general principles, not specific instructions given to each individual individually. Whatever the means are, whether legislation or precedent is chosen in communicating standards of action, all of these, however fluent they may be to solve a large number of ordinary cases, law proves to be uncertain. ${ }^{45}$

Claes et.al state that the law's 'open texture' occurs because legal norms that are expressed in words are unable to formulate a form of legal action in its entirety. This is because of the limitations of words to explain all the things the legislators want. For example, a norm says, "Vehicles may not enter the park". People will realize that the norm prohibits the use of cars and motorbikes to enter the park. However, there can be other questions. Is roller-skating allowed? Does that include vehicles? Therefore, an interpretation is needed to solve that problem. ${ }^{46}$ This concept is in line with Kelsen that norm (including law) is a scheme of interpretation. ${ }^{47}$

To understand interpretation, we can start by understanding the concept of interpretation, also known as hermeneutics. Hermeneutics, from the Greek, means interpret (hermeneuine), interpretation (hermenia), or "to express one's thoughts in words". ${ }^{48}$ Palmer says hermeneutics (interpretation) is the process of changing something or a situation of ignorance into understanding. ${ }^{49}$ Interpretation can also be interpreted as process, method, act of interpreting, or an attempt to explain the meaning of something unclear. ${ }^{50}$ Thus, interpretation is an activity to find or achieve the "meaning" of something. ${ }^{51}$

This study is of position that norm and interpretation cannot be said to be two completely different entities. An interpretation can be a norm and vice versa. For example, in Islam, the Hadith (sayings) of the Prophet Muhammad (Peace be Upon $\mathrm{Him}$ ) is an interpretation of the Holy Quran. Both Quran and Hadith can be

\footnotetext{
$44 \quad$ lbid., pp. 353-355.

$45 \quad$ Hart, op.cit., pp. 124-127

46 Erik Claes et al., "The Limits of the Law" dalam Erik Claes, Wouter Devroe, and Bert Keirsbilck (Ed.), Facing the Limits of the Law, Berlin: Springer, 2009, p. 14.

47 Hans Kelsen, Pure Theory of Law, translated from the Second (Revised and Enlarged) German Edition by Max Knight, New Jersey: The Lawbook Exchange, 2005, pp. 54-58.

48 Mardian Wibowo, Kebijakan Hukum Terbuka dalam Putusan Mahkamah Konstitusi: Konsep dan Kajian dalam Pembatasan Kebebasan Pembentuk Undang-Undang, Depok: RajaGrafindo Persada, First Printing, 2019, p. 8.

49 Ilham B. Saenong, Hermeneutika Pembebasan: Metodologi Tafsir Al-Qur'an menurut Hassan Hanafi, Jakarta: Teraju, 2002, p. 23.

50 Kamus Besar Bahasa Indonesia, "tafsir", https://kbbi.web.id/tafsir, accessed on December 2020.

51 F. Budi Hardiman dalam Mardian Wibowo, op.cit., pp. 8-9.
} 
considered norms or rules that must be obeyed by Muslims, considering that the position of the Quran is higher than the Hadith. ${ }^{52}$ Likewise, this pattern of relationship occurs between constitution and law. Law is an interpretation of constitution made by the lawmakers. Both constitution and laws are legal norms that must be obeyed by all parties. Constitution is superior to law that interprets it..$^{53}$ Therefore, an interpretation cannot be stated to be completely different from the norm. It can even be stated that a certain thing can have multiple functions, namely as an interpretation and a norm. Thus, it makes sense for Kelsen to argue that authentic interpretation creates the norm. ${ }^{54}$

Kelsen provides an example of the form of the norm as well as interpretation. For example, a criminal code may contain an article that states,

"Murder must be understood as the behavior of an individual who deliberately causes the death of another individual".

The article defines murder, which has the characteristics of a norm if it is tied by another article,

"If a person commits murder, the competent court must sentence him to death".

However, the norms that state the command to impose the death penalty do not specify what kind of death penalty should be administered. Therefore, the lawmakers make other norms to interpret the form of the death penalty that law enforcers must implement, for example, "the death penalty must be carried out by hanging". This norm is also tied to the previous norm because the norm that interprets the death penalty form will be useless if the norm that mandates the death penalty does not exist. Because the interpretation is always tied to the entity it interprets, Kelsen calls it a dependent norm..$^{55}$

The norm that interprets the form of the death penalty is also a norm in the form of command because this norm instructs law enforcers to carry out the death penalty by hanging and not by other means. Thus, the interpretation does not mean only containing formulas in the form of definition or meaning, such as " $x$ is $y^{\prime \prime}$. It can also be in the form of other sentence formulations, including the formulation of the command sentence mentioned earlier.

The opinion that interpretation is a form of norms is conveyed implicitly by Manan. According to him, the definition/meaning in Article 1 or the general provision of the law, which are official or authentic interpretation, have the power as law. Manan states that interpretation in the form of meanings in general

\footnotetext{
52 Relit Nur Edi, “As-Sunnah (Hadits) (Suatu Kajian Aliran Ingkar Sunnah)”, Asas, Vol. 6, No. 2, July 2014, p. 133.

53 Hans Kelsen, Pure Theory of Law, translated from the Second (Revised and Enlarged) German Edition by Max Knight, op.cit., pp. 353-355.

$54 \quad$ Ibid., p. 58.

$55 \quad$ Ibid., pp. 56-58.
} 
provision has power as law. Therefore, Manan also recognizes that interpretation in the form of definition/meaning is a legal norm. ${ }^{56}$

In contrast to the above view, concerning the law elucidation, the 2011 Legislation Establishment Law separates interpretation and norm as two entirely different things. As regulated in the Attachment II of the Law, the elucidation is the interpretation of the body's norms. Therefore, the elucidation only contains descriptions of foreign words, phrases, sentences, or equivalent words/terms in the norm, which can be completed by examples.

There are two components to the elucidation: the general elucidation part and the elucidation of the article-by-article part. General elucidation contains "a systematic description of the background of the thought, aim, and objective of drafting law and regulation". The article-by-article elucidation stipulates that it "does not include norm"; "may not conflict with the main material in the body of the law"; "does not add, narrow, or expand the meaning of norms in the body of the law"; "does not repeat the subject matter on the body of the law"; "does not repeat the meaning, term, description of words, or phrases of the general provisions"; "does not regulate the delegation formula"; "cannot be a legal basis for the establishment of further regulations"; and "does not make hidden changes to the provisions in the body of the law".

In practice, the regulation that places elucidation as only an interpretation and not containing norms is difficult to implement. The examples are the elucidations of the six laws before the independence era, have been and have not been reviewed by the Constitutional Court and have presented before or after the Establishment of Legislation Law was formed, as well as related to constitutional law issues (covering issues of state organization and human rights). ${ }^{57}$ They are, among others, the Law Number 1 of 1946 on the Criminal The Law Regulation (Criminal The Law Regulation); the Law Number 1/PNPS/1965 on the Prevention of Abuse and/or Blasphemy of Religion (Blasphemy The Law); Law Number 31 of 1999 on Eradication of Corruption Crime as amended by the Law Number 20 of 2001 (Eradication of Corruption Crime The Law); Law Number 25 of 2002 on the Establishment of the Riau Islands Province (Riau Islands Law); Law Number 39 of 2008 on the State Ministry (State Ministry Law); and Law Number 7 of 2012 on Social Conflict Management (Social Conflict Management Law). The material content of the elucidation of various laws, either general elucidation or article-byarticle elucidation, in Indonesia can be categorized into seven categories as follows: ${ }^{58}$

\footnotetext{
56 Bagir Manan, Hukum Kewarganegaraan Indonesia dalam Undang-Undang Nomor 12 Tahun 2006, op.cit., p. 59.

57 Michael T. Molan, Textbook: Constitutional and Administrative Law: The Machineary of Government, $4^{\text {th }}$ edition, London: Old Bailey Press, 2003, p. 2.

58 The description is a categorization of all elucidation material content from the 6 laws that have been previously mentioned, but not all material content is included here due to page limitations so only examples are included.
} 
Table 1. Category of Law Elucidation and Example

\begin{tabular}{|c|c|c|}
\hline No. & $\begin{array}{l}\text { Category of Law } \\
\text { Elucidation }\end{array}$ & Example of Law Elucidation \\
\hline 1 & Definition/meaning & $\begin{array}{l}\text { Definition: } \\
\text { " "Restitution" is the payment of compensation for damage } \\
\text { to property and/or suffering suffered by the victim and/or } \\
\text { his family." } \\
\text { (Elucidation of Article } 37 \text { of the Social Conflict Management } \\
\text { Law) } \\
\text { Definition limit: } \\
\text { "... the criminal acts referred to here are those that are } \\
\text { solely (in essence) aimed at the intention of being hostile or } \\
\text { insulting." } \\
\text { (Elucidation of Article } 4 \text { letter a of the Blasphemy Law) } \\
\text { Scope: } \\
\text { "Facility is defined as preferential treatment given in various } \\
\text { forms, for example, unreasonable loan interest, } \\
\text { unreasonable price, granting of executive licenses, including } \\
\text { import duty or tax relief that is contrary to the prevailing } \\
\text { Laws and regulations." } \\
\text { (General Elucidation of the Eradication of Corruption Crime } \\
\text { Law) }\end{array}$ \\
\hline 2. & Command & $\begin{array}{l}\text { "After one year of inauguration of the Riau Islands Province, } \\
\text { the Governor of Riau and the Governor of the Riau Islands } \\
\text { are obliged to report the implementation of the handover as } \\
\text { referred to in this paragraph to the Minister of Home Affairs } \\
\text { for further policymaking." } \\
\text { (Elucidation of Article } 14 \text { paragraph (2) of the Riau Islands } \\
\text { Law) }\end{array}$ \\
\hline 3. & Stipulation & $\begin{array}{l}\text { The stipulation of authority: } \\
\text { "The investigator's authority in this Article includes the } \\
\text { power to carry out wiretapping." } \\
\text { (Elucidation of Article } 26 \text { of the Eradication of Corruption } \\
\text { Crime Law) } \\
\text { The stipulation of rights: } \\
\text { "... Because these } 6 \text { kinds of religions are religions that are } \\
\text { practiced by almost the entire population of Indonesia, } \\
\text { unless they get the guarantee as provided by article } 29 \\
\text { paragraph } 2 \text { of the Constitution, they also get assistance and } \\
\text { protection as provided by an article this...." } \\
\text { (Elucidation of Article } 1 \text { of the Blasphemy Law) }\end{array}$ \\
\hline
\end{tabular}




\begin{tabular}{|c|c|c|}
\hline & & $\begin{array}{l}\text { The stipulation regarding the validity or invalidity of } \\
\text { something: } \\
\text { "Currency or paper money that is not mentioned in the } \\
\text { Declaration of the President of the Republic of Indonesia } \\
\text { dated October } 3,1945, \text { No. } 1 / 10 \text { as a legal means of } \\
\text { payment, is the illegal payment instrument for Java and } \\
\text { Madura." } \\
\text { (Elucidation of Article IX to Article XIII of the Criminal Law } \\
\text { Regulation) } \\
\text { The stipulation of certain conditions for a situation/activity: } \\
\text { "If there are } 2 \text { (two) or more cases which are determined by } \\
\text { Law to take precedence, the determination of priority of the } \\
\text { case is submitted to each competent institution in each } \\
\text { judicial process." } \\
\text { (Elucidation of Article } 25 \text { of the Eradication of Corruption } \\
\text { Crime Law) } \\
\text { The stipulation of position/status of person: } \\
\text { "The meaning of "Deputy Minister" is a career official and is } \\
\text { not a member of the cabinet." } \\
\text { (Elucidation of Article } 10 \text { of the State Ministry Law which the } \\
\text { Constitutional Court has annulled) } \\
\text { The stipulation of procedures for implementing norms in } \\
\text { the body: } \\
\text { "Appreciation to the public who has contributed to exposing } \\
\text { criminal acts of corruption accompanied by evidence, are } \\
\text { given awards in the form of certificates and premiums." } \\
\text { (Elucidation of Article } 42 \text { paragraph (1) of the Eradication of } \\
\text { Corruption Crime Law) } \\
\text { implementing rules/provision of the delegation: } \\
\text { the content of the Government Regulation includes } \\
\text { (Elucidation of Article } 34 \text { of the Social Conflict Management } \\
\text { Law) }\end{array}$ \\
\hline 4. & Exception/deviation & $\begin{array}{l}\text { "Persons sentenced to prison for political reasons and who } \\
\text { have received rehabilitation are exempted from this } \\
\text { provision." } \\
\text { (Elucidation of Article } 22 \text { paragraph (2) letter f of the State } \\
\text { Ministry Law) }\end{array}$ \\
\hline 5. & Reference & Reference to other section of the Law: \\
\hline
\end{tabular}




\begin{tabular}{|l|l|l|}
\hline & & $\begin{array}{l}\text { "The purpose of this provision has been sufficiently explained } \\
\text { in the general elucidation above." } \\
\text { (Elucidation of Article 4 of the Blasphemy Law) } \\
\text { Reference to other rules: } \\
\text { "It is the same as 'Verordening No. 18 van het Militair } \\
\text { Gezag'." } \\
\text { (Elucidation of Article XIV of the Criminal Law Regulation) }\end{array}$ \\
\hline 6. & Paraphrase & $\begin{array}{l}\text { "That the results of peaceful dispute resolution must be } \\
\text { respected, obeyed, and implemented by all parties to the } \\
\text { conflict." } \\
\text { (Elucidation of Article 8 paragraph (3) of the Social Conflict } \\
\text { Management Law) }\end{array}$ \\
\hline 7. & $\begin{array}{l}\text { The background or } \\
\text { aim and objective of } \\
\text { establishing } \\
\text { abolishing, } \\
\text { amending certain } \\
\text { law or article/norm } \\
\text { in the Body of the } \\
\text { law }\end{array}$ & $\begin{array}{l}\text { "This article is incompatible with the form of our State as a } \\
\text { Republic." } \\
\text { (Elucidation of Article VIII No. 19 of the Criminal Law } \\
\text { Regulation) }\end{array}$ \\
*Note: this category is always the content of the General \\
Description.
\end{tabular}

The table above shows that the law elucidation contains many interpretations with formulas that are generally categorized as norms, namely command, stipulation, and deviation/exception. Apart from that, the law elucidation also in practice includes the definition/meaning, reference, paraphrase, and background of the establishment of a norm. If we refer to Kelsen's opinion, then definitions/meanings such as definition, definition limit, or scope are included as the norm. If the definition, scope, or definition limit cannot be called a norm, then the territorial coverage or boundaries that are usually the dominant content within the body of the law on the establishment of certain regions cannot be declared as norms. This is because the formulations of articles regarding territorial coverage and boundaries can be categorized as definition limits or scope boundaries. Article 1, which usually contains definitions or definition limits, Manan says that this has a legal character (norm). ${ }^{60}$ Therefore, it is clear that a definition, definition limit, or scope can be stated as a norm.

Furthermore, reference is also a norm if you see the number of articles or paragraphs in the body of the law that contain this. The reference is actually related to the meaning of other norms in the same or other laws. ${ }^{61}$ Paraphrasing or

59 Maria Farida, Ilmu Perundang-undangan 2, op.cit., p. 96.

60 Bagir Manan, Hukum Kewarganegaraan Indonesia dalam Undang-Undang Nomor 12 Tahun 2006, op.cit., p. 59

61 Ibid., p. 222. An example of reference is Article 8 paragraph (2) of the Establishment of Legislation Law of 2011 which states, "The laws and regulations as referred to in paragraph (1) are recognized for their existence 
repeating sentences in different languages may or may not become the norm, depending on the form of the paraphrased formulation/sentence.

The only category that cannot be categorized as a norm is the background for the formation of the norm. The background usually contains facts, aims, objectives, or thoughts that cannot be called norms, something regulatory. This can only be categorized as a form of interpretation. Either it is historical, sociological, comparative, or other interpretation, depending on what facts, aims, objectives, or thoughts are included in the law elucidation. ${ }^{62}$

The existence of an interpretation in the form of a (new) norm in the elucidation does not always mean that there will be a conflict with the body of the law. For example, Article 26 in the Body of the Eradication of Corruption Crime Law states,

"Investigation, prosecution, and trial in court against criminal acts of corruption are carried out under the applicable criminal procedural the Law, unless otherwise stipulated in this law."

The elucidation of the article states that, "The investigator's authority in this Article includes the power to carry out wiretapping". This elucidation does not contradict Article 26 or other articles in the body of the law. In fact, with the elucidation of this article, investigators have a clearer understanding of their authority, namely that they can carry out wiretapping in carrying out investigations into criminal acts of corruption. However, it should still be acknowledged that several new norms in the elucidation could contradict the body of the law, such as the elucidations that were annulled by the Constitutional Court.

Thus, it can be seen that the material legal status of the law elucidation in Indonesia can be interpreted in the form of the norm (definition, command, the stipulation of authority, etc.) or interpretation that are not in the form of the norm (thought, aim, objective, and sociological fact, historical fact, comparative fact, or other facts). The provisions in the Attachment II of the 2011 Legislation Establishment Law states as follows.

"The elucidation only contains descriptions of foreign words, phrases, sentences, or equivalents of foreign words/terms in the norm which can be accompanied by examples"

In reality or practice, it often contains formulations that are generally categorized as norms. Therefore, once again, it can be said that the prohibition on the inclusion of norms in the elucidation by the 2011 Legislation Establishment Law is not effective. Compared with other states, the regulation, in the Netherlands or Australia, the law elucidation cannot contain the norms that do not exist. The

and have binding legal force as long as they are ordered by higher laws and regulations or established based on authority." Reference is also widely stated in the Criminal Provision.

62 Maria Farida, IImu Perundang-undangan 2, op.cit., p. 96. 
article-by-article elucidation (artikelsgewijze toelichting in the Netherlands and 'notes on clause' in Australia) must be made briefly to ensure that there are no duplicates between the general elucidation and the article-by-article elucidation. There is no need to paraphrase the articles in elucidation or there is no need to make an elucidation if the article does not require elucidation.

In both states, law elucidation focuses more on the general elucidation (algemeen deel van de memorie van toelichting in the Netherlands or general outline in Australia). It describes in-depth background of the law establishment; conformity with other legislations (equivalent or higher, either the constitution or the international law); the expected consequences or implications as well as side effects of the establishment of the law; the financial consequences or implications that arise if the bill becomes law; the implementation, supervision, and evaluation of the law in effect; the law enforcement based on time and context; etc. ${ }^{63}$

Altogether, memorie van toelichting in the Netherlands has the following structures and contents. ${ }^{64}$

\section{1) General Elucidation (algemeen deel van de memorie van toelichting)}

a) Introduction: show briefly (a maximum of ten lines) what the content is and needs of the law.

b) Implementing regulations: this section only needs to be included if the law is required in connection with the application of international regulations, such as European Union (EU) directives or regulations or other binding EU legal agreements. This section will provide a brief and objective description of the scope and main elements of international regulations to be applied and will briefly consider the reason and background. If the applied international regulations are amendments to existing international regulations, then the international regulation schemes that exist in the national implementation regulations will be discussed.

c) The law's main points: will discuss the reasons, problem descriptions, problem approaches, and instrument choices, as well as the purpose and need for regulation. Attention is also paid to the underlying policy theory (all the assumptions and research findings on which to base the conclusion that the proposed regulation solves the problem in question). The point is to clarify the law's considerations, including the considered variants and the criteria that played a role in the formation of the law.

d) Relationship to a higher regulation: this section shows the law complies with the higher regulation.

63 Kenniscentrum Wetgeving en Juridische zaken, "Bouwstenen Voor de Memorie Van Toelichting", https://www.kcwj.nl/kennisbank/schrijfwijzer-memorie-van-toelichting/bouwstenen-voor-de-memorie-vantoelichting, accessed on August 2020. Also read: Australian Government, Legislation Handbook, Canberra: Department of the Prime Minister and Cabinet, 2017, pp. 38-41.

64 Kenniscentrum Wetgeving en Juridische zaken, ibid. 
e) Relationship to national the law: this section shows how the law complies with the various rules in the applicable national legal system and any draft regulations that is currently being prepared.

f) Consequences: discusses the most important (non-financial) consequences, such as the desired effect and the regulation's side effect.

g) Execution: discusses the implementation aspect if the law takes effect.

h) Supervision and the law enforcement: this section shows how compliance supervision/monitoring and the law enforcement are regulated.

i) Financial consequences: this section shows the financial consequences and costs arising from the regulation. Even if there are no financial consequences, this should be clearly stated in the elucidation.

j) Evaluation: discusses how the law will be evaluated after it comes into effect and explains the evaluation period.

k) Advice and consultation: this part contains suggestions on the law and matters discussed during consultations with communities, organizations, etc.

I) Transitional rules and when they come into force: explain why the law that will take effect is enforced on a certain date, whether the law will take effect gradually, etc.

\section{2) Article-by-Article Elucidation (artikelsgewijze toelichting)}

This must be made briefly, make sure there are no duplicates between the general elucidation and the article-by-article elucidation, and there is no need to paraphrase the article in the elucidation or there is no need to make the elucidation if the article does not require elucidation.

\section{3) Attachment of Elucidation (bijlagen bij de toelichting).}

On the other hand, the explanatory memorandum in Australia has the following structure and content. ${ }^{65}$

1) Cover Sheet, which consists of:

a) a year in which a parliamentary session is taking place (as indicated in the bill) and covers each subsequent year, ending with the year of introduction;

b) a title 'The Parliament of the Commonwealth of Australia';

c) name of the chamber of parliament (House of Representative or Senate) where the bill was first introduced;

d) a short title of the bill;

e) a statement that the memorandum is being circulated by the relevant portfolio minister authority;

f) different information is required on the cover of an explanatory memorandum depending on what the memorandum is:

i. for the bill introduced the first time;

65 Australian Commonwealth, Legislation Handbook, op.cit., pp. 37-45. 
ii. to accompany amendments from the government;

iii. replacement of the memorandum;

iv. correction/addendum to memorandum;

v. for use in the second house where the bill has been amended in the first chamber; or

vi. for more than one bill.

2) General Outline, which consists of:

a) a short title of the bill at the top of the page

b) a brief but clear statement of the aim or objective of the bill or amendment to it;

c) an outline of why the bill or amendment is required, the effect of the main provision, and an explanation of the policy background;

d) a financial impact statement describing both the direct and indirect financial impacts of the Commonwealth of the proposed bill including savings, expenses, income losses or gains, or changes in the position of net assets or fiscal balances resulting from the bill;

e) a regulation impact statement, where required;

f) a statement of compatibility with human rights.

\section{3) Notes on clauses or amendments.}

These are intended to accompany clauses or amendments to the bill and must be designed in such a way that it can be accessed and understood by the law users, both experts and non-experts. The note also takes into account matters considered by the Senate Committee for Supervision of the Bill. The note should avoid repeating words in the bill or amendment or repetitions in alternative languages (paraphrasing). Because these notes are published, they do not include any material that is not suitable for public release. Ideally, the notes on the clauses (with equivalent requirements for notes to amendments) would:

a) state the origin and aim of the clause by specifying what actions the clause provides and how it appears (including the reasons why the clause is structured in a particular way and when the clause starts);

b) give an example of the desired effect of the clause or problem to be resolved;

c) explain how the clause fits into the existing legislative framework (if appropriate) and relates it to other provisions in the bill, especially if the related clauses do not appear sequentially in the bill;

d) consider and adjust the contents of the notes to suit the audience; for example, general concerns about the regulations of a particular business or interest group that could be affected by the bill;

e) describe the policy underlying the bill to help courts interpret potentially ambiguous provisions by explaining the policy's intent behind the clause or 
clause amendment. This is especially important because the explanatory memorandum is extrinsic material that courts may refer to under section $15 A B$ of Acts Interpretation Act 1901 when interpreting the law;

f) address significant problems that have arisen during consultations on legislation;

g) stand alone as much as possible, so that the notes on clauses can be read separately and give the reader a complete understanding of the reasons for changing the law without having to read the entire explanatory memorandum. In some cases, such as when an amendment involves several important changes, it may be useful to group multiple notes on clauses together; and

h) note on clauses should:

i. start on a new page;

ii. given a serial number;

iii. follow the financial impact statement, regulatory impact statement (if required), and human rights compatibility statement;

iv. have an internal paragraph number;

v. have consistent use of acronyms;

vi. have a center or shoulder heading for each clause or clause group - the heading is expected to be the same as the heading in the bill for that clause or clause group; and

vii. all pages are numbered in series following the outline (not including the cover sheet).

From the discussion above, it can be seen that both in Netherlands and Australia, there is no prohibition on the law elucidation to include a formula containing norm and various other prohibitions that are prohibited in the 2011 Legislation Establishment Law. This is reasonable because, as previously explained, law elucidation in both countries is not part of the law framework and is not promulgated, so they are not binding. Because it is not promulgated, even though it contains formulations in the form of norms such as commands, stipulations, definitions, and so on, the elucidation in the Netherlands and Australia is only a non-binding (and can be distorted) interpretation for judges or other the law enforcers.

\section{c. Evaluation of The Law Elucidation Arrangements in the Indonesian Legislation System}

If we look at history, the law elucidation is a legacy from Netherlands. ${ }^{66}$ Previously it has been found and explained that the law elucidation in Indonesia (the Dutch East Indies) has the same formal legal status as the memorie van toelichting in the

$66 \quad$ Jimly Asshiddiqie, op.cit., p. 133. 
Netherlands, which is separated from the law framework and not promulgated. ${ }^{67}$ In Australia, the law elucidation is not part of the law framework. ${ }^{68}$ Therefore, the study is on position to argue that the current law elucidation arrangements should be evaluated and put back in line with its initial concept.

The making of the elucidation as part of the law framework and promulgating it have been proven to create losses because if there is a conflict with the body of the law, it will cause legal uncertainty to the community who is also bound by the elucidation. Therefore, the Constitutional Court has canceled several elucidations until now because it is considered detrimental and violates the 1945 Constitution. If the elucidation is separated from the law framework and not promulgated, then this will not happen because the elucidation only serves as an interpretation, regardless of the content or formulation contained therein.

By separating the elucidation from the law framework and not being promulgated, the legislators will not include essential material in the elucidation because if it is included in the elucidation, the material will not be binding, even though the material is made to bind and obey the public. Therefore, legislators will focus more on including these essential materials in the body of the law by separating the elucidation from the law framework.

Furthermore, even lower rule-makers will not use the law elucidation as a legal basis because they know for sure that the law elucidation is a non-binding entity and will only focus on making regulations ordered in the body of the law or accordance with the body of the law only.

Regarding the material legal status or what kind of content should be in the elucidation, the authors argue that there is no need for prohibitions such as being prohibited from containing norms; expanding, narrowing, or adding to the meaning of norms in the body of the law; etc. The author argues, it is difficult to limit the formulation of sentences from an interpretation. It could be that at some point, the interpretation will be clearer when it is made in the form of a normative sentence. When limited, it is possible that the interpretation made to clarify something even makes it unclear. Therefore, prohibitions in the 2011 Legislation Establishment Law are currently unnecessary unless the prohibition of elucidations contradicts the body of the law and repeats the material already in the body of the law.

The prohibition of the elucidation contrary to the body of the law is still needed so that the elucidation is useful to clarify something, not cause uncertainty. In addition, the prohibition that also exists in Netherlands and Australia, namely not to repeat the material that is in the body of the law (either in the same language or paraphrase) is needed because the elucidation should not be made for mere formality and should not make the elucidation that does not clarify what it means listed in the body of the law.

\footnotetext{
Ichtiar Baru-van Hoeve, op.cit., pp. 1759, 1787.

Patrick O’Neill, op.cit., p. 7.
} 
The authors also suggest that an elucidation, either a general elucidation or the article-by-article elucidation, explains the aim and objective of forming a law in general and also the aim and objective of the articles, such as in the Netherlands and Australia which focus on this in the formation of elucidation. ${ }^{69}$ Currently, in Indonesia, the article-by-article elucidations often describe the definition of a word or phrase without explaining the aim and objective of each article and its relation to the overall material of the law. By explaining these aims and objectives, the judge or other the law enforcer will know best on how to apply the law in general or article-by-article of the law.

\section{The Law Elucidation as the Object of Judicial Review of the Constitutional Court}

As described in the introduction, the Constitutional Court, for the first time, conducted a review of the law elucidation in 2005, namely in case Number 005/PUU-III/2005. The law elucidation becomes the review's object because the elucidation is part of the law framework and is binding because it is promulgated in the Supplement to the Official Gazette. This is in accordance with Article 57 of The Law Number 24 of 2003 on the Constitutional Court, ${ }^{70}$ which states as follows.

"(1) The decision of the Constitutional Court which ruling states that the material contained in paragraphs, articles and/or parts of the law is contrary to the 1945 Constitution of the Republic of Indonesia, the material contains paragraphs, articles, and/or parts of the law does not have binding legal force.

(2) The decision of the Constitutional Court which rulings state that the establishment of the law does not fulfill the provisions of the establishment of a law based on the 1945 Constitution of the Republic of Indonesia, the law does not have binding legal force.

(3) The decision of the Constitutional Court which approves the application must be promulgated in the Official Newspaper at the latest 30 (thirty) working days after the decision is pronounced."

After that, nine other Decree of the Constitutional Courts reviewed the law elucidation. Based on these decisions, it can be seen the extension for the Constitutional Court to review and to annul the elucidation. The elucidation: (1) contains new norms; (2) is contrary to the norms on the body of the law; (3) creates an out of sync with the provisions in the body of the law; (4) chaotic implementation of laws, causing legality problems; (5) obscures the norms it describes; (6) makes covert changes to the legislation concerned; (7) has a different

\footnotetext{
69 Kenniscentrum Wetgeving en Juridische zaken, "Bouwstenen Voor de Memorie Van Toelichting”, op.cit., Also read: Australian Government, op.cit., pp. 38-41.

$70 \quad$ Last amended by Law Number 4 of 2014.
} 
meaning from the body of the law; (8) annuls clear norms; (9) is inconsistent and causes multiple interpretations; (10) causes confusion in the implementation of the law; ${ }^{71}(11)$ is contrary to other the Law; ${ }^{72}$ and (12) directly contradicts the 1945 Constitution. ${ }^{73}$ The Constitutional Court can also provide new legal norms on elucidations with conditionally constitutional/unconstitutional decisions in accordance with the Decree of the Constitutional Court Number 18/PUU-XVII/2019.

The authors argue this is appropriate, apart from the statement that the elucidation can be reviewed and annulled if it contains (new) norms. The previous sub-chapter has been explained that, until now, many elucidations contain formulations in the form of norms (commands, stipulations, and so on). The existence of (new) norms in the elucidation, as previously explained, does not always contradict the body of the law. Therefore, if a (new) norm in the elucidation does not conflict with the body of the same law, with other laws regulating the same substance, or with the 1945 Constitution, then there is no urgency to annul the norm because there is no violation of constitutional rights and it does not create legal uncertainty.

Review and annulment can only be carried out if the elucidation contradicts the body of the same law, with other law regulating the same substance, or the 1945 Constitution. The elucidation can be annulled when it contradicts the same body of the law or with other law regulating the same substance (not directly contradicting the 1945 Constitution) because the Decree of the Constitutional Court Number 49/PUU-XI/2011 states the Constitutional Court can review a law against other laws if they conflict and create legal uncertainty. ${ }^{74}$ This means that it also applies if there is a conflict between norms or between provisions in the law.

Since the elucidation (if it contains the formulation of the norm) is the legal norm that is tied by the provision on the body of the law, it is clear that the provisions contained in the body of the law must take precedence if there is a conflict between the two. The Constitutional Court can also add new norms with conditionally constitutional/unconstitutional decision ${ }^{75}$ to the law elucidation because the elucidation is currently part of the binding law framework, just like the body of the law. The conditionally constitutional/unconstitutional decision marks so that a previously existing norm can still be constitutional/valid or so that a previously existing norm does not become unconstitutional. ${ }^{76}$

However, if in the future the law elucidation is no longer included in the law framework and is not promulgated in the Supplement to the Official Gazette, the

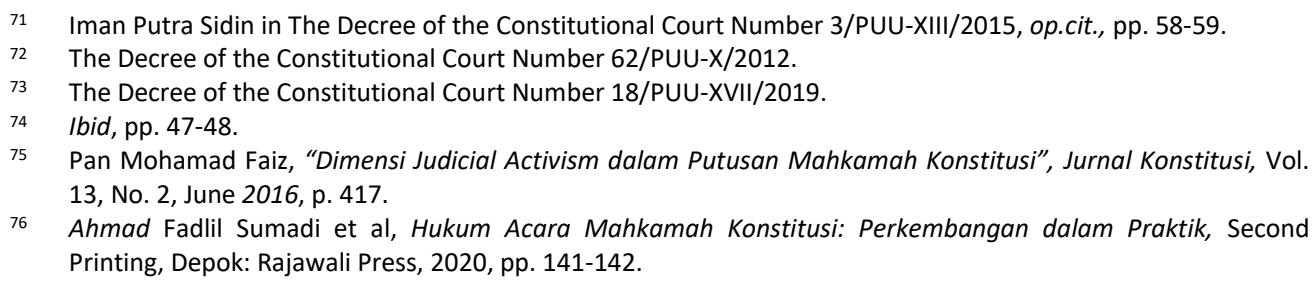


Constitutional Court will no longer need to review the elucidation. This is because unregulated elucidation, as in the Netherlands and Australia, is not legally binding norms.

The separation of the elucidation from the law framework is beneficial for states like the Netherlands that do not have a judicial review instrument on the law. In the Netherlands, if there is a conflict between the elucidation and the body of the law, judged will not carry out the review and annul the elucidation. The judge only needs to deviate or not apply the law elucidation and only apply the body of the law. ${ }^{77}$ Likewise, if the law elucidation in Indonesia is separated from the law framework, the Constitutional Court does not need to review the law elucidation if the content is problematic.

Suppose that one day the law elucidation is no longer promulgated in the Supplement to the Official Gazette. Then, it turns out that there is a conflict between the elucidation and the body of the law, but the Constitutional Court considers what is stated in the elucidation to be more appropriate. The court can review the body of the law by using a conditionally constitutional/unconstitutional decision. In addition, they can make the formula stated in the elucidation as a new norm in the articles in the body of the law.

\section{Conclusion}

Conclusion can be drawn that formally; the law elucidation has a binding legal force. It is a part of the law framework and promulgated in the Supplement to the Official Gazette. On the other hand, materially, the law elucidation in the current Indonesian legislation system has two forms: an interpretation in the form of the norm (definition, command, stipulation, deviation, and reference) or an interpretation that are not in the form of the norm (thought, aim, objective, and sociological fact, historical fact, comparative fact, or other facts).

As an object of judicial review, the Constitutional Court can review and annul the law elucidation that contradicts: (1) the body of the same law; (2) other laws that regulate same substance; or (3) 1945 Constitution. The Constitutional Court can also make conditionally constitutional/unconstitutional decision that add new norm to the elucidation because currently, the elucidation is part of the law framework that is binding, just like the body of the law.

Furthermore, the study is on the position that the elucidation's formal legal status should not be made part of the law framework and not promulgated in accordance with the initial concept of its formation as a non-binding interpretation during the Dutch East Indies era. Such formal legal status enable the Constitutional Court no longer needed to annul the elucidation if the content was problematic.

\footnotetext{
77 Kenniscentrum Wetgeving en Juridische zaken, "Schrijfwijzer Memorie Van Toelichting", https://www.kcwj.nl/kennisbank/schrijfwijzer-memorie-van-toelichting, accessed on August 2020.
} 
Lastly, regarding the material legal status or the kind of content should be in the elucidation, there is no need for prohibitions such as being prohibited from containing, expanding, narrowing, or adding norms to the meaning of norms in the body of the law and so on. It is difficult to limit the formulation of sentences from an interpretation. It could be that at some point, the interpretation will be clearer when it is made in the form of a normative sentence. Limited interpretation can make something unclear. Furthermore, the elucidation should also further deepen the aims and objectives of the existence of articles-by-article, not only explaining the aims and objectives of the law in general. By explaining the law's aims and objectives in general and the articles, judge or other law enforcers will know better how to apply law in general or to apply each article of the law.

\section{References}

\section{Books}

Ahmad Fadlil Sumadi (et.al), Hukum Acara Mahkamah Konstitusi: Perkembangan dalam Praktik, Second Printing, Rajawali Press, Depok, 2020.

Australian Government, Legislation Handbook, Department of the Prime Minister and Cabinet, Canberra, 2017.

Bagir Manan, Dasar-Dasar Perundang-Undangan Indonesia, Ind-Hill.Co, Jakarta, 1992.

, Hukum Kewarganegaraan Indonesia dalam Undang-Undang Nomor 12 Tahun 2006, First Printing, FH UII Press, Yogyakarta, 2009.

Claes, Erik, Wouter Devroe, and Bert Keirsbilck (Ed.), Facing the Limits of theLaw, Springer, Berlin, 2009.

Kelsen, Hans, General Theory of The Law and State, Translated by Anders Wedberg, Harvard University Press, Cambridge, 1949.

, Pure Theory of The Law, translated from the Second (Revised and Enlarged) German Edition by Max Knight, The Lawbook Exchange New Jersey, 2005.

Hart, H. L. A., The Concept of The Law, Second Edition, Oxford University Press, New York, 1994.

Ichtiar Baru-van Hoeve, Himpunan Peraturan Perundang-undangan Republik Indonesia, Ichtiar Baru-van Hoeve, Jakarta, 1992.

Ilham B. Saenong, Hermeneutika Pembebasan: Metodologi Tafsir Al-Qur'an menurut Hassan Hanafi, Teraju, Jakarta, 2002.

Vlies, Inge Cornelia van der, Buku Pegangan Perancang Peraturan Perundangundangan, translated by Linus Doludjawa, Direktur Jenderal Peraturan Perundang-undangan Departemen Hukum dan Hak Asasi Manusia RI, Jakarta, 2005.

Jimly Asshiddiqie, Perihal Undang-Undang, Third Printing, Rajawali Press, Jakarta, 2014. 
Johny Ibrahim, Teori dan Metodologi Penelitian Hukum Normatif, Bayu Media Publishing, Malang, 2006.

Mardian Wibowo, Kebijakan Hukum Terbuka dalam Putusan Mahkamah Konstitusi: Konsep dan Kajian dalam Pembatasan Kebebasan Pembentuk Undang-Undang, First Printing, Rajawali Press, Depok, 2019.

Maria Farida Indrati Soeprapto, Ilmu Perundang-undangan 1 (Jenis, Fungsi, dan Materi Muatan), Kanisius, Yogyakarta, 2018.

, Ilmu Perundang-undangan 2 (Proses dan Teknik

Penyusunan), Kanisius, Yogyakarta, 2018.

Molan, Michael T., Textbook: Constitutional and Administrative the Law: The Machinery of Government, $4^{\text {th }}$ edition, Old Bailey Press, London, 2003.

Ratno Lukito, Perbandingan Hukum: Perdebatan Teori dan Metode, Gadjah Mada University Press, Yogyakarta, 2016.

Soerjono Soekanto and Sri Mamudji, Penelitian Hukum Normatif: Suatu Tinjauan Singkat, UI Press, Jakarta, 2003.

Sri Hajati (et.al), Buku Ajar Pengantar Hukum Indonesia, Second Printing, Pusat Penerbitan dan Percetakan Universitas Airlangga, Surabaya, 2018.

\section{Other Documents}

Ari Wirya Dinata, "Lembaga Jaminan Fidusia: Pasca Putusan Mahkamah Konstitusi Nomor 18/PUU-XVII/2019", Nagari The Law Review, Vol. 3, No. 2, 2020.

Bagus Hermanto (et.al), "Penegasan Kedudukan Penjelasan Suatu Undang-Undang: Tafsir Putusan Mahkamah Konstitusi", Jurnal Legislasi Indonesia, Vol. 17, No. 3, 2020.

Kennis-en Exploitatiecentrum Officiële Overheidspublicatie, "Veelgestelde vragen over Wet- en regelgeving", https://www.overheid.nl/veelgesteldevragen/veelgestelde-vragen-over-wet-en-regelgeving\#BWB004.

Kenniscentrum Wetgeving en Juridische zaken, "Bouwstenen voor de memorie van toelichting", $\quad$ https://www.kcwj.nl/kennisbank/schrijfwijzer-memorie-vantoelichting/bouwstenen-voor-de-memorie-van-toelichting.

"Schrijfwijzer memorie van toelichting", https://www.kcwj.nl/kennisbank/schrijfwijzer-memorie-vantoelichting.

Ministerie van Justitie en Veiligheid, "Besluit van de Minister-President, Minister van Algemene Zaken, van 22 december 2017, nr. 3215945, houdende vaststelling van de tiende wijziging van de Aanwijzingen voor de regelgeving", https://zoek.officielebekendmakingen.nl/stcrt-2017-69426.html.

O'Neill, Patrick, “'Was there an EM?'-Explanatory memoranda in the Commonwealth Parliament 1901-82", Australian The Law Librarian, Vol. 13, No. $1,2005$. 
Oly Viana Agustine, "Putusan Mahkamah Konstitusi dalam Pembangunan Ekonomi Nasional pada Pemuliaan Tanaman dan Alat Berat", Jurnal Rechtsvinding, Vol. 7, No. 1, 2018.

Pan Mohamad Faiz, "Dimensi Judicial Activism dalam Putusan Mahkamah Konstitusi", Jurnal Konstitusi, Vol. 13, No. 2, 2016.

Universiteit Utrect, "Wet- en regelgeving: Nederlandse wetgeving", https://libguides.library.uu.nl/c.php?g=202157\&p=1331397.

\section{Legal Documents}

Acts Interpretation Act 1901.

Besluit van de Minister-President, Minister van Algemene Zaken, van 22 december 2017, nr. 3215945, houdende vaststelling van de tiende wijziging van de Aanwijzingen voor de regelgeving, Staatscourant 2017, 69426.

Law Number 1 of 1946 on Criminal the Law Regulations [Undang-Undang Nomor 1 Tahun 1946 tentang Peraturan Hukum Pidana].

Law Number 1/PNPS/Year 1965 on the Prevention of Religious Abuse and/or Blasphemy [Undang-Undang Nomor 1/PNPS/Tahun 1965 tentang Pencegahan Penyalahgunaan dan/atau Penodaan Agama].

Law Number 31 of 1999 on Eradication of Corruption Crime [Undang-Undang Nomor 31 Tahun 1999 tentang Pemberantasan Tindak Pidana Korupsi].

Law Number 20 of 2001 on Amendments to The Law Number 31 of 1999 on Eradication of Corruption Crimes [Undang-Undang Nomor 20 Tahun 2001 tentang Perubahan atas Undang-undang Republik Indonesia Nomor 31 Tahun 1999 tentang Pemberantasan Tindak Pidana Korupsi].

Law Number 25 of 2002 on the Establishment of the Riau Islands Province [Undang-Undang Nomor 25 Tahun 2002 tentang Pembentukan Provinsi Kepulauan Riau].

Law Number 24 of 2003 on the Constitutional Court [Undang-Undang Nomor 24 Tahun 2003 tentang Mahkamah Konstitusi].

Law Number 39 of 2008 on State Ministries [Undang-Undang Nomor 39 Tahun 2008 tentang Kementerian Negara].

Law Number 12 of 2011 on the Formation of The Laws and Regulations [UndangUndang Nomor 12 Tahun 2011 tentang Pembentukan Peraturan Perundangundangan].

Law Number 7 of 2012 on Handling of Social Conflict [Undang-Undang Nomor 7 Tahun 2012 tentang Penanganan Konflik Sosial].

Presidential Decree Number 44 of 1999 on Techniques for Formulating Legislation and Forms of Draft The Laws, Draft Government Regulations, and Draft Presidential Decrees [Keputusan Presiden Nomor 44 Tahun 1999 tentang Teknik Penyusunan Peraturan Perundang-undangan dan Bentuk Rancangan UndangUndang, Rancangan Peraturan Pemerintah, dan Rancangan Keputusan Presiden]. 
Decree of the Constitutional Court Number 005/PUU-III/2005 [Putusan Mahkamah Konstitusi Nomor 005/PUU-III/2005].

Decree of the Constitutional Court Number 011/PUU-III/2005 [Putusan Mahkamah Konstitusi Nomor 011/PUU-III/2005].

Decree of the Constitutional Court Number 003/PUU-IV/2006 [Putusan Mahkamah Konstitusi Nomor 003/PUU-IV/2006].

Decree of the Constitutional Court Number 11-14-21-126 and 136/PUU-VII/2009 [Putusan Mahkamah Konstitusi Nomor 11-14-21-126 dan 136/PUU-VII/2009].

Decree of the Constitutional Court Number 57/PUU-IX/2011 [Putusan Mahkamah Konstitusi Nomor 57/PUU-IX/2011].

Decree of the Constitutional Court Number 79/PUU-IX/2011 [Putusan Mahkamah Konstitusi Nomor 79/PUU-IX/2011].

Decree of the Constitutional Court Number 62/PUU-X/2012 [Putusan Mahkamah Konstitusi Nomor 62/PUU-X/2012].

Decree of the Constitutional Court Number 3/PUU-XIII/2015 [Putusan Mahkamah Konstitusi Nomor 3/PUU-XIII/2015].

Decree of the Constitutional Court Number 42/PUU-XIII/2015 [Putusan Mahkamah Konstitusi Nomor 42/PUU-XIII/2015].

Decree of the Constitutional Court Number 18/PUU-XVII/2019 [Putusan Mahkamah Konstitusi Nomor 18/PUU-XVII/2019]. 